\title{
Experimental testing of a helical rotor for compost distribution
}

\author{
Vasilica Ștefan ${ }^{1 *}$, Ladislau David ${ }^{2}$, Radu Ciupercă $^{1}$, Ana Zaica ${ }^{1}$, Ancuţa Nedelcu$^{1}$ and \\ Albert Suvac ${ }^{1}$ \\ ${ }^{1}$ INMA Bucharest, Romania, 013811, Ion Ionescu de la Brad Bv.,Bucharest, Romania \\ ${ }^{2}$ UPB Romania, 060042, Splaiul Independentei, 313, Bucharest, Romania
}

\begin{abstract}
It is well known that a manure spreader must be able to apply manure consistently, effectively and uniformly over the time. An overapplying doze will cause serios environmental problems ( pollution) and a sub-applying doze will not contribute to plants growth and the applying of the fertilizer will be a loss. Corroborate with others problems such as maintaining a constant tractor speed, a constant rotational speed of the rotor, a constant and continuous flow of the material make the manure spreading machines an important subject for study and continuously improving . The propose of this study is to test a vertical helicoidal rotor for manure spreading in order to improve the machine distribution uniformity. The relation between the rotor position and rotation sense is a definitory issue for the machine performance. In order to achieve a high distribution uniformity a single helical rotor is tested and a series of possible situations of placing four rotors on the machine are analyzed. The optimal solution is given by two indicators: uniformity of spreading and distribution width. The test were made with an helical rotor having the following characteristics: high $=1,1 \mathrm{~m}$, maximum diameter of helical spiral $=0.345 \mathrm{~m}$, minimum diameter of the helical spiral $=0.114 \mathrm{~m}$, helical pitch $=0.3 \mathrm{~m}$, inclination angle $=15^{\circ}$. After analyzing four possible situations it is observe that the combination of the maximum uniformity with minimum distribution with is the optimal solution. Experimental were carried out with compost and can be repeatable with others type of solid organic fertilizers, but a new calibration should be done. It is desirable that a trapezoidal, oval or triangle pattern with uniform sloping sides to be achieved. Because most of the spreaders actually produce an oval or triangle distribution pattern it is necessary subsequent passes that increase the time for fertilization operation.
\end{abstract}

\section{Introduction}

Manure management can have both beneficial effects, influencing the chemical and physical properties of soil, such as microbial activity, but it can also have disadvantages if application rates are not properly managed and controlled. This can be a major cause of soil quality deterioration and a source of pollution of water sources [1, 2, 3, 4]

\footnotetext{
* Corresponding author: valle vali@yahoo.com
} 
In order to reduce the polluting effects, efforts are made both for the production of high quality fertilizer products (compost, vermicompost) and for the production of highperformance technical equipment $[5,6,7]$.

The machines for distributing solid organic fertilizers has to distribute uniformly the fertilizers on the soil, that are later incorporated into the soil according to the agrotechnical requirements of the crop plants. They must meet the following requirements $[8,9,7,10]$;

- $\quad$ to distribute a wide range of organic fertilizers;

- $\quad$ to achieve the fertilization norm imposed by the agrotechnical requirements;

- $\quad$ achieve uniformity of distribution according to the regulations (minimum 75\%);

- be able to work on horizontal and sloping grounds;

- to allow the adjustment of the quantity of fertilizers administered per hectare (the norm);

- $\quad$ achieve a proper degree of shredding (particles larger than $6 \mathrm{~cm}$ not to exceed $25 \%)$

- the machines are easy to operate (preparation of work and transport, filling and emptying with material, supervision of the work process);

- have a high working capacity that allows the works to be carried out during the optimum agrotechnical time);

- $\quad$ to maintain the initial working conditions during the work;

- have a low energy consumption;

- not to present danger of injury to the user.

The uniformity of the distribution is of great importance, because an uneven distribution makes in some areas the quantity of fertilizers to be smaller, not ensuring the expected effect, or, high concentrations of fertilizer are causing local pollution of the soil [11].

The uniformity of fertilizer distribution depends on a number of factors such as: $[1,12$, $13,14]$

- $\quad$ properties of distributed materials: humidity, density;

- the adjustments and the dimensions of the machine: the speed of the distributing rotors, the distance between the rotors, the diameter, the pitch and the shape of the helical coil, the inclination in vertical plane of the rotors, - the mode of feeding the distribution apparatus: maintaining a constant and continuous supply flow;

- $\quad$ the distance from the surface of the soil;

- external conditions: wind speed, terrain slope.

A decisive factor influencing both the norm distributed per hectare and the uniformity of distribution are: inconsistent machine speed that can reach up to $25 \%$ and the inconsistent rotational speed of the rotors or inconsistent conveyor speed $[9,15,10]$.

In order to achieve a high performant fertilizer machine, some experimental researches were made. A single helical rotor was tested and some recommendations were made.

\section{Material and method}

To perform the tests with a single rotor, the volume of the MG-5 spreader was divided into two areas by installing a partition wall, so that the material was placed to feed a single rotor (Fig.1). The vertical rotor shape and components were described in fig.2. The material used was compost. 


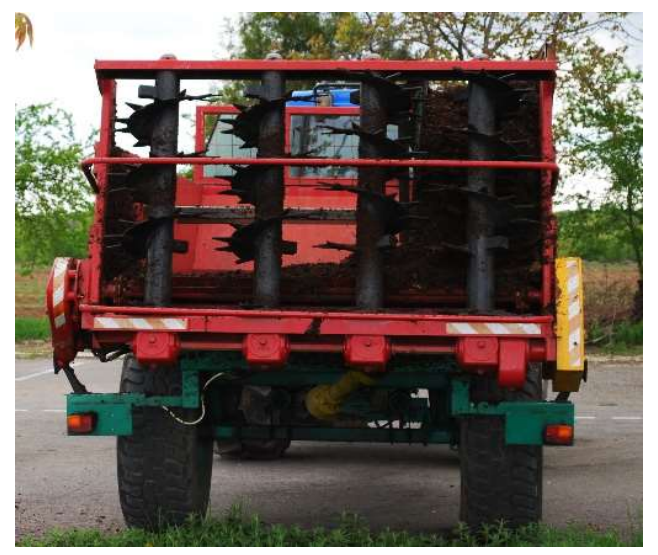

Fig. 1. MG 5 manure spreader

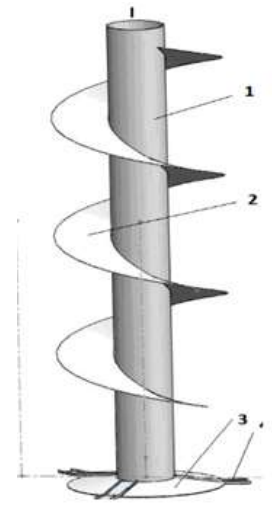

Fig.2. Helical rotor : 1) shaft; 2) helical spiral; 3)disc; 4)palette

The following initial data were considered:

- $\quad$ Rotor speed $n=540 \mathrm{rpm}$;

- The maximum diameter of the helical coil $\varnothing_{\max }=0.345 \mathrm{~m}$;

- The minimum diameter of the helical coil $\varnothing_{\min }=0.115 \mathrm{~m}$;

- The pitch of the helical coil $p=0.3 \mathrm{~m}$;

- High of the rotor $h=0.9 \mathrm{~m}$;

- Distance between rotor base and the soil $d=1.2 \mathrm{~m}$;

- The inclination of the rotor and vertical axis $\alpha=15^{\circ}$ (rotor inclination of $15^{\circ}$ corresponds to the horizontal throwing of fertilizer particles leaving the helical coil at its maximum diameter $0.345 \mathrm{~m}$ )

- Material density: $\rho=510 \mathrm{~kg} / \mathrm{m}^{3}$;

- $\quad$ Dry matter $u=72.33 \%^{\circ}$;

- $\quad$ Conveyor speed $v_{t r}=0.006 \mathrm{~m} / \mathrm{s}$;

- Material flow $q=1.53 \mathrm{~kg} / \mathrm{s}$.

The distribution was carried out at the stationary on a concrete platform and the collection of the material was collected from each square meter belonging to the distributed surface, placed in plastic bags and then weighed individually (Fig.3 and 4).

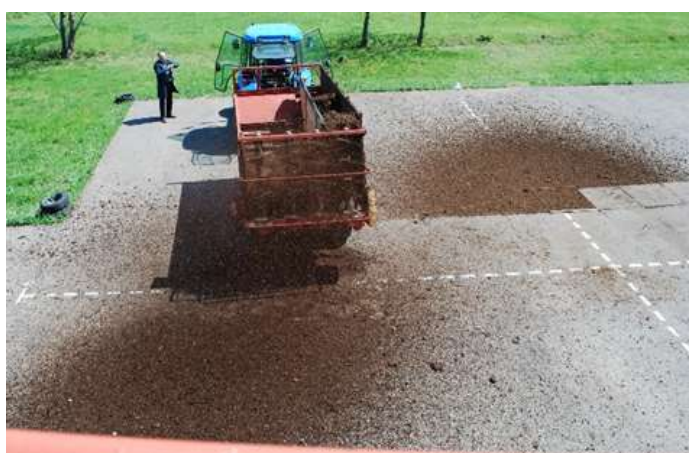

Fig.3. Compost distribution on concrete platform

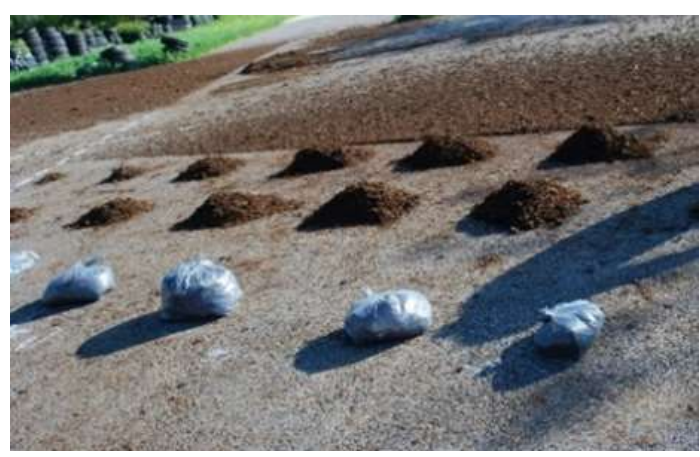

Fig.4. Collecting the samples 


\section{Results and discussion}

The quantities of material distributed for 25 seconds on the total area are weighed individually and presented in table 1 . It is observed that the total width is $9 \mathrm{~m}(5 \mathrm{~m}$ to the left of the rotor axis and $4 \mathrm{~m}$ to the left of it) and the length is $11 \mathrm{~m}$.

Table 1. The amount of material distributed (Compost) per unit area ; $\mathrm{n}=540 \mathrm{rpm}$, theoretical flow $\mathrm{q}=1.53 \mathrm{~kg} / \mathrm{s}, \mathrm{t}=25 \mathrm{~s}$.

\begin{tabular}{|c|c|c|c|c|c|c|c|c|c|c|}
\hline \multicolumn{11}{|c|}{ Amount of material distributed per unit area $\left[\mathrm{kg} / \mathrm{m}^{2}\right]$} \\
\hline & & \multicolumn{9}{|c|}{ Width, m } \\
\hline & & -4.5 & -3.5 & -2.5 & -1.5 & -0.5 & 0.5 & 1.5 & 2.5 & 3.5 \\
\hline \multirow{11}{*}{ 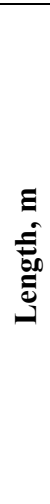 } & 0.5 & 0 & 0 & 0 & 0 & 0 & 0 & 0 & 0 & 0 \\
\hline & 1.5 & 0 & 0 & 0 & 0 & 0 & 0 & 0 & 0 & 0 \\
\hline & 2.5 & 0 & 0 & 0 & 0 & 1.062 & 0.512 & 0 & 0 & 0 \\
\hline & 3.5 & 0 & 0.224 & 0.497 & 0.596 & 1.155 & 1.041 & 0.694 & 0.280 & 0.315 \\
\hline & 4.5 & 0.041 & 0.240 & 0.954 & 1.295 & 1.170 & 0.775 & 2.309 & 0.470 & 0.170 \\
\hline & 5.5 & 0.087 & 0.248 & 0.852 & 1.063 & 1.322 & 1.954 & 1.608 & 1.035 & 0.329 \\
\hline & 6.5 & 0.029 & 0.490 & 0.652 & 0.926 & 1.275 & 1.055 & 1.256 & 1.205 & 0.462 \\
\hline & 7.5 & 0.027 & 0.147 & 0.379 & 0.857 & 0.480 & 0.780 & 1.170 & 1.065 & 0.550 \\
\hline & 8.5 & 0 & 0.076 & 0.582 & 0.700 & 0.280 & 0.980 & 0.275 & 0.660 & 0.325 \\
\hline & 9.5 & 0 & 0.087 & 0.021 & 0.255 & 0.240 & 0.500 & 0.105 & 0.107 & 0.025 \\
\hline & 10.5 & 0 & 0 & 0 & 0.025 & 0.005 & 0.102 & 0.047 & 0 & 0 \\
\hline
\end{tabular}

The values were divided with 25 for finding the amount of material distributed in 1 second. The transversal distribution was determinate (table 2).

Table 2. Transverse distribution obtained with one rotor.

\begin{tabular}{|c|c|c|c|c|c|c|c|c|c|c|}
\hline & \multicolumn{10}{|c|}{ Amount of material distributed per unit area } \\
\hline & \multicolumn{10}{|c|}{ Width] } \\
\cline { 2 - 11 } & -4.5 & -3.5 & -2.5 & -1.5 & -0.5 & 0.5 & 1.5 & 2.5 & 3.5 & Total \\
\hline $\begin{array}{c}\text { Specific flow } \\
\text { in 25 s, kg/ m }\end{array}$ & $\begin{array}{c}0.18 \\
5\end{array}$ & $\begin{array}{c}1.51 \\
2\end{array}$ & $\begin{array}{c}3.93 \\
7\end{array}$ & $\begin{array}{c}5.71 \\
7\end{array}$ & 6.99 & 7.7 & $\begin{array}{c}7.46 \\
6\end{array}$ & $\begin{array}{c}4.82 \\
2\end{array}$ & $\begin{array}{c}2.17 \\
6\end{array}$ & $\begin{array}{c}\mathbf{4 0 . 5 0} \\
7\end{array}$ \\
\hline $\begin{array}{c}\text { Specific flow } \\
\text { in 1 sec, } \mathbf{~ k g / s} \\
\mathbf{~ m}^{2}\end{array}$ & $\begin{array}{c}0.00 \\
7\end{array}$ & $\begin{array}{c}0.06 \\
0\end{array}$ & $\begin{array}{c}0.15 \\
7\end{array}$ & $\begin{array}{c}0.22 \\
8\end{array}$ & $\begin{array}{c}0.27 \\
9\end{array}$ & $\begin{array}{c}0.30 \\
8\end{array}$ & $\begin{array}{c}0.29 \\
8\end{array}$ & $\begin{array}{c}0.19 \\
2\end{array}$ & $\begin{array}{c}0.08 \\
7\end{array}$ & $\mathbf{1 . 6 2 0}$ \\
\hline
\end{tabular}

Based on the values obtained with a single rotor, the optimum variant of positioning 4 rotors is determined in order to obtain the best distribution. The rotational speeds of 540 $\mathrm{rpm}$ and an inclination angle of $15^{\circ}$ were considered. Since the width of the machine is 2 $\mathrm{m}$, the rotors are located at a distance of $0.5 \mathrm{~m}$ between them. Rotor 1 and rotor 2 are lefthanded spiral and rotor 3 and 4 are right-Händel spiral. The rotors R1 and R2 rotate clockwise and the rotors R3 and R4 rotate trigonometrically.

Possible variants of location of the 4 rotors are shown in figure 5: 
a

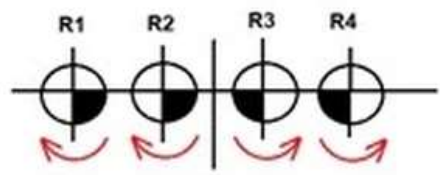

b

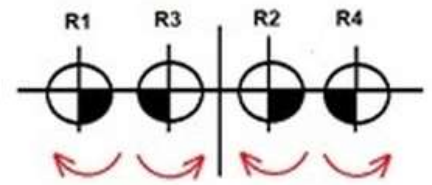

c

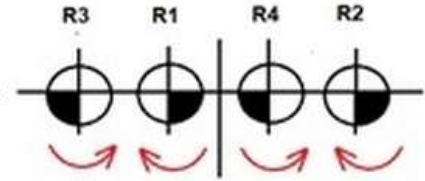

d

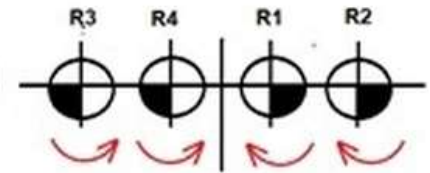

Fig.5.Variants for the location and operation of the distributor rotors a) variant 1 ; b) variant 2 ; c) variant 3 ; d) variant 4

Considering that the experiments were performed with the rotor number 4 (R4), the direction of rotation and the distance between the rotors are taken into account and the amount of material distributed on each square meter is calculated similar to the previous calculations. The following results are obtained.

In variant 1 for the location of the rotors, the rotors R1 and R2 rotate clockwise and the rotors R3 and R4 rotate counter-clockwise.

It has been made the assumption that all rotors have a similar distribution, given the course of the winding direction. Considering the distribution made by 1 rotor (table 2), the cross-sectional distribution made by the machine in variant 1 of rotor placement was calculated graphically (fig.6).

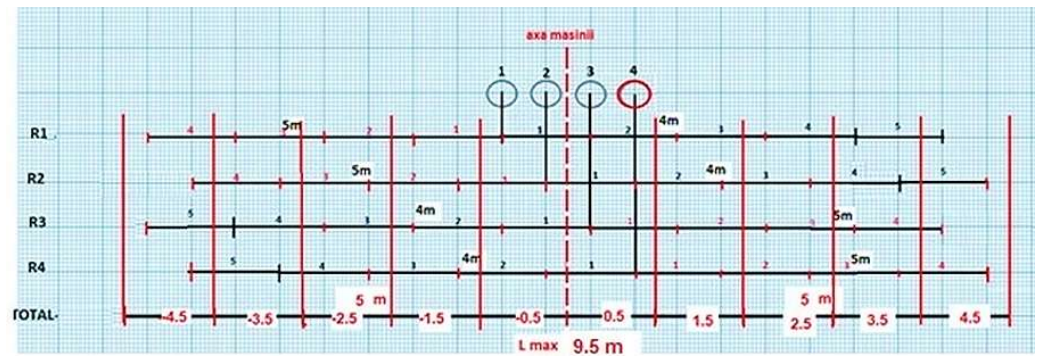

Fig.6. The overlap of the obtained distribution of 4 rotors-variant 1 .

Considering the overlap of the surfaces obtained in the case of the 4 distributor rotors mounted on the machine in variant 1 with and summing the quantities distributed by each rotor on each linear meter (fig.7) the data from table 3 are obtained.

Table 3. The transverse distribution realized by 4 rotors located in - Variant 1.

\begin{tabular}{|c|c|c|c|c|c|c|c|c|c|c|}
\hline \multicolumn{11}{|c|}{ Specific flow $\left[\mathrm{kg} / \mathrm{s} \mathrm{m}^{2}\right]$} \\
\hline $\begin{array}{c}\text { Width, } \\
{[\mathrm{m}]}\end{array}$ & -4.5 & -3.5 & -2.5 & -1.5 & -0.5 & 0.5 & 1.5 & 2.5 & 3.5 & 4.5 \\
\hline R1 & 0.065 & 0.166 & 0.272 & 0.305 & 0.286 & 0.241 & 0.175 & 0.084 & 0.020 & 0.001 \\
\hline R2 & 0.021 & 0.113 & 0.219 & 0.301 & 0.300 & 0.266 & 0.210 & 0.133 & 0.047 & 0.005 \\
\hline R3 & 0.005 & 0.047 & 0.133 & 0.210 & 0.266 & 0.300 & 0.301 & 0.219 & 0.113 & 0.021 \\
\hline R4 & 0.001 & 0.020 & 0.084 & 0.175 & 0.241 & 0.286 & 0.305 & 0.272 & 0.166 & 0.065 \\
\hline TOTAL & 0.094 & 0.347 & 0.709 & 0.992 & 1.095 & 1.095 & 0.992 & 0.709 & 0.347 & 0.094 \\
\hline
\end{tabular}

The distribution of the fertilizer in variant 1 has a maximum specific flow of 1.095 $\mathrm{kg} / \mathrm{m} 2 \cdot \mathrm{s}$. The obtained distribution width is $9.5 \mathrm{~m}$, as it can be observed in fig.6. 
Similarly, the distributions of fertilizers made by the 4 rotors in variant 2 variant 3 and variant 4 are calculated and the results are presented in table 4 and fig. 7 .

Table 4. The cross-sectional distribution made by 4 distributing rotors

\begin{tabular}{|c|c|c|c|c|c|c|c|c|c|c|c|c|}
\hline \multicolumn{13}{|c|}{ Specific flow, $\left[\mathrm{kg} / \mathbf{s ~ m}^{2}\right]$} \\
\hline $\begin{array}{c}\text { Width } \\
{[\mathbf{m}]}\end{array}$ & $\mid-5.5$ & -4.5 & $\mid-3.5$ & -2.5 & -1.5 & -0.5 & 0.5 & 1.5 & 2.5 & 3.5 & 4.5 & 5.5 \\
\hline $\begin{array}{c}\text { Variant } \\
1\end{array}$ & & 0.075 & 0.331 & 0.708 & 0.990 & 1.096 & 1.096 & 0.990 & 0.706 & 0.329 & 0.075 & \\
\hline $\begin{array}{c}\text { Variant } \\
2 \\
\end{array}$ & 0.001 & 0.074 & 0.320 & 0.693 & 0.991 & 1.119 & 1.119 & 0.991 & 0.692 & 0.318 & 0.073 & 0.001 \\
\hline $\begin{array}{c}\text { Variant } \\
3\end{array}$ & 0.005 & 0.071 & 0.299 & 0.662 & 0.995 & 167 & 167 & 0.995 & 662 & 0.297 & 0.069 & 0.005 \\
\hline $\begin{array}{c}\text { Variant } \\
4\end{array}$ & 0.007 & 0.069 & 0.288 & 0.647 & 0.997 & 1.191 & 1.191 & 0.997 & 0.647 & 0.286 & 0.067 & 0.007 \\
\hline
\end{tabular}

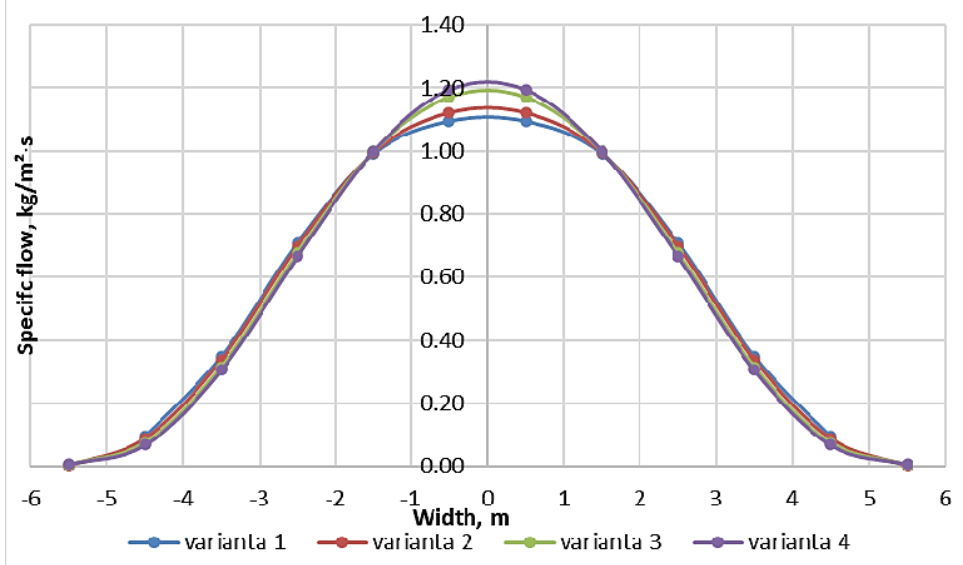

Fig.7. Comparison between all 4 variants of rotors placement

From fig. 7 it is observed that in variant 2 the obtained distribution width has the value $\mathrm{L}$ $=11.5 \mathrm{~m}$ and the maximum of the specific flow reaches the value of $1.1205 \mathrm{~kg} / \mathrm{m}^{2} \cdot \mathrm{s}$. For variant 3 of the location of the rotors the obtained distribution width is $11.5 \mathrm{~m}$ and the maximum is $1.1697 \mathrm{~kg} / \mathrm{m}^{2} \cdot \mathrm{s}$. For variant 4 we obtain a width of $10.5 \mathrm{~m}$ and a maximum of the specific material flow of $1.1942 \mathrm{~kg} / \mathrm{m}^{2} \cdot \mathrm{s}$.

The uniformity degree of the distribution (eq. 1) for each proposed variant, at a single pass of the machine (U1) was calculated. After eliminating from the calculation the extreme values, which are not representative the corrected uniformity U2 was obtained. The values obtained are presented in table 5 .

$$
U=\left[1-\frac{\sqrt{\frac{\sum_{1}^{j}\left(m_{i}-m_{\text {med }}\right)^{2}}{j-1}}}{m_{\text {med }}}\right] \cdot 100
$$

where $m_{i}$ are the quantities of material collected from the soil from each square meter, $m_{m e d}$ is their arithmetic mean and $j$ is the number of collected samples. 
Table 5. Uniformity of distribution for all 4 variants

\begin{tabular}{|c|c|c|c|c|}
\hline \multirow{2}{*}{ Uniformity } & \multicolumn{4}{|c|}{ Variant location of the rotors } \\
\cline { 2 - 5 } & $\mathbf{1}$ & $\mathbf{2}$ & $\mathbf{3}$ & $\mathbf{4}$ \\
\hline $\mathbf{U}_{\mathbf{1}}[\%]$ & $\mathbf{4 3 . 7 0}$ & 17.03 & 14.13 & 12.71 \\
\hline $\mathbf{U}_{\mathbf{2}}[\%]$ & $\mathbf{6 0 . 5 6}$ & 35.49 & 33.41 & 31.55 \\
\hline
\end{tabular}

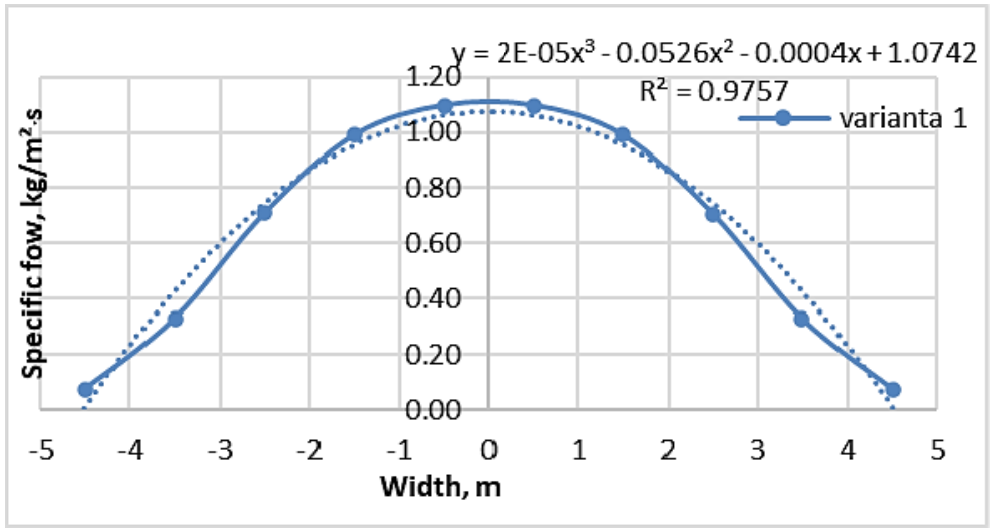

Fig.8. Optimal transverse distribution curve.

The optimal theoretical curve obtained (fig.8) is symmetrical to the axis of the machine, it has an oval/Gaussian shape and implies the need to study the optimal distance for the next steps of the machine so that the uniformity of the entire fertilizer distribution work is maximum.

This paper was financed by grant of the Romanian Education and Research Ministry, through Programme 1 - Development of the national research-development system, subprogramme 1.2 - Institutional performance - Projects for financing excellence in RDI, contract no. 16PFE.

\section{Conclusions}

In the experimental tests performed at the speed of the distributor rotor, $\mathrm{n}=540 \mathrm{rpm}$ the amount of material distributed in 25 seconds was $44.48 \mathrm{~kg}$, which corresponds to a specific flow rate of $1.6203 \mathrm{~kg} / \mathrm{s} \mathrm{m}^{2}$. In this case the width of distribution was $9 \mathrm{~m}$, the largest quantity of material being in the center of the surface and towards the extremities it decreases.

When testing the machine at stationary, considering that the width of the machine is 2 $\mathrm{m}$, the location of the inclined rotors with $15^{\circ}$ is made at a distance of $0.5 \mathrm{~m}$ between them in 4 variants.

In version 1 (rotors R1 and R2 rotate clockwise and rotors R3 and R4 rotate counterclockwise) the speed of the distributing rotors of $540 \mathrm{rpm}$ and the specific flow of 1.2159 $\mathrm{kg} / \mathrm{m}^{2} \cdot \mathrm{s}$, the distribution width obtained is of $9.5 \mathrm{~m}$ and the degree of uniformity of the distribution is maximum.

At a single pass of the machine the degree of uniformity of the distribution is, along the whole width of distribution $\mathrm{U}_{1}=43.7 \%$ and after eliminating from calculation the extreme values, on which fertilizers will be distributed on the next passage, $U_{2}=60.57 \%$. 


\section{References}

1. Antile D.L., Gallar L., Miller P.C.H.,Godwin R.J., "An investigation into the fertilizer particle dynamics off-the disc," Appl. Eng. in Agr., vol. 31, no. 1, pp. 49-60, 2015.

2. Landry H., Lague C., Roberge M., "Physical and rheological properties of manure products," Appl. Eng. in Agr., vol. 20, no. 3, pp. 277-288, 2004.

3. Vanotti M.B., Rashash D.M.C., Hunt P.G, " Solid-liquid separation of flushed swine manure with PAM: Effect of wastewater strenght," Trans. of ASAE, vol. 45, pp. 19591969, 2002.

4. Ștefan (Popa) V., Ciupercă R., Popa L., Nedelcu A., Lazăr G., Petcu A.S., Zaica A., "Influenţa caracteristicilor fizice ale îngrăşămintelor organice solide asupra calităţii lucrării de împrăştiere," INMATEH Agr. Eng., vol. 46, no. 2, pp. 77-84, 2015.

5. Bohnhoff D., Converse J., "Engineering properties of separated manure solids," Biological Wastes, vol. 19, pp. 91-106, 1987 .

6. Ciupercă R., Lazăr G., Popa L., Nedelcu A., Ștefan V., Zaica A., Petcu A., "Sistem ecologic de gestionare a deșeurilor vegetale și animale," INMATEH - Agr. Eng., vol. 46, no. 2, pp. 69-76, 2015.

7. Nedelcu A., Ciupercă R., Popa L., Zaica A, Zaica Al, Anghelet A., Ștefan V, Cristescu A.C., "Aspects about organic waste composting in biocontainer," in ISB INMA TEH, Bucharest, 2018.

8. Cârdei P., Ștefan V., Matache M.G., "Mathematical models for calculating the qualitative parameters of organic fertilizer machines," in Research people and actual tasks on multidisciplinary sciences, Lozenec, Bulgaria, 2019.

9. ASABE Standards S341:4, Procedure for measuring distribution uniformity and calibrating granular broadcast spreaders, St. Joseph, Mich: ASABE, 2009.

10. Robert P. C., "Precision agriculture: a challenge for crop nutrition management," Plant and Soil, vol. 247, pp. 143-149, 2002.

11. Rousselet M., Mozoyer J. , " Évaluation des performances des épandeurs de fumier: premiers results selon la norme NF EN 13080," Ingénieries, vol. 46, pp. 79-92, 2006.

12. Ștefan V., Popa L., David L., Pirnă I., Ciupercă R., Petcu A., Duţu M. F., Găgeanu I , "Considerations on physical and mechanical properties of solid organic fertilizers," in 4th Int. Conf. on Therm. Equip., Ren. Energ., Posada, România, 2015.

13. Malgeryd J., Watterberg C, "Physical Properties of Solid and Liquid Manures and their Effect on the Performance of Spreading machines," J. of Agr. Eng. Res., vol. 64, no. 4, pp. 289-298, 1996.

14. Popa L., Pirnă I., Cojocaru I., Ciupercă R., Nedelcu A., Ștefan V., "Machine for applying manure fertilizers by means of vertical spreading apparatus," in Sc. Conf. Dur. Agri., Craiova, Romania, 2008.

15. Babiciu P., Studiul interdependenței dintre parametrii aparatelor de împrăștiere prin centrifugare și uniformitatea de distribuție pe sol a îngrăşămintelor minerale, Teza de doctorat, București: Facultatea de Mecanica Agricolă - UPB, 1976.

16. Ștefan V., Cârdei P., Popa L., David L., Ciupercă R., "Influenta parametrilor regimului de lucru al masinilor de fertilizare organică, asupra performanțelor calitative ale procesului de fertilizare," INMATEH Agr. Eng., vol. 58, no. 2, pp. 115-120, 2019. 